"This is the peer reviewed version of the following article: [Australian Journal of Public Administration, 2020], which has been published in final form at https://onlinelibrary.wiley.com/journal/14678500]. This article may be used for non-commercial purposes in accordance with Wiley Terms and Conditions for Self-Archiving." 


\section{Legislating deliberative engagement: Is local government in Victoria willing and able?}

Running head: Deliberative engagement in Victoria?

Emanuela Savini

Industry Fellow and $\mathrm{PhD}$ Candidate

Institute for Public Policy and Governance

University of Technology Sydney

PO Box 123 Broadway, NSW 2007

Australia

Email: Emanuela.Savini@student.uts.edu.au

Bligh Grant

Associate Professor

Institute for Public Policy and Governance

University of Technology Sydney

PO Box 123 Broadway, NSW 2007

Australia

Email: Bligh.Grant@uts.edu.au

The authors declare no real or perceived conflict of interest in the research and potential publication of this work or a revised version thereof. 


\title{
Legislating deliberative engagement: Is local government in Victoria willing and able?
}

\begin{abstract}
:
Growing dissatisfaction with representative democracy, and concomitantly, the increasing expectation that citizens assert more influence over public policy, have seen the emergence of more participatory and deliberative forms of governance in public management practice. This article explores the attempt of the state government of Victoria, Australia to legislate for mandatory deliberative engagement as part of its local government strategic planning instruments. The ambition of the reform was significant; however, it was almost unanimously rejected by the local government sector. Based on analysis of the keythemes that emerged from the submissions made during the three-year Victorian LocalGovernment Act Review process, we explore the limitations and barriers to implementing deliberative engagement practice at a local government level. We demonstrate that whilst the promise of participatory democracy might have been compelling, in the case of Victoria there were a series of contextual and capacity considerations that needed to be taken into account before the implementation of such reforms were pursued.
\end{abstract}

Key words Deliberative democracy; local government reform; participatory governance; Victorian local government.

\section{Summary at a glance}

This article explores the attempt to legislate deliberative engagement as a strategic planning instrument during the Victorian Local Government Act Review process. We demonstrate that whilst the promise of participatory democracy might have been compelling, there were limitations to implementing this practice which needed to be considered in the reform.

\section{Introduction}

Democratic innovations that expand the influence of citizens have become de rigueur in political and administrative sciences over the past few decades, both in Australia (Dryzek 2012; Hartz-Karp and Briand 2009; Hendricks 2012) and internationally (Curato et al. 2017; Fishkin 2011; Goodin 2008; Parkinson \& Mansbridge 2012; Saward 2000). Christensen and Grant (2016, p. 462) argue that participatory democracy is grounded in a belief that it is active citizens who know best about the common good, and as such ought to contribute to 
decision-making. The normative basis of participatory practice is that a group of citizens is more likely to be unhindered by bias or political persuasion and can therefore make, or can contribute to the making of decisions in the best interest of their fellow citizens. Moreover, this participation serves to bolster democracy in the face of claims of a 'democratic deficit' (Norris 2011). The 'promise' of participatory and deliberative engagement is therefore a compelling counterbalance to what are perceived as the limitations of elected representatives and the institutional structures of government.

In Australia, whilst there have been several incremental reforms embracing participatory and deliberative procedures over the past two decades, principally through strategic planning instruments legislated by state governments for their local governments (see Grant and Drew 2017, pp. 217-264) alongside heightened support for the practices of deliberation in the for-profit and not-for-profit sectors (see Christensen and Grant 2019; IAP2 2019; newDemocracy n.d.) deliberative practice has been implemented on an ad-hoc basis. To date, there haven't been the government reforms that systematically institutionalise democratic innovations, or modernise the government-citizen relationship, such as those that have been pursed in other countries (see, for example, the Community Empowerment [Scotland] Act 2015; New Zealand's Local Government Act 2002 and the Local Government (Auckland Council) Act 2009). That said, deliberative practice has clearly gained interest in Australia. For instance, a survey of 352 councils across four Australian jurisdictions found that one third of councils intended to use participatory budgeting, deliberative group methods and co-design in the next-12 months (Christensen 2018). Although there is interest in the practice, questions remain regarding what how the practice is to be developed and embedded in government institutions (see, for example, Christensen and Grant 2019).

Against this backdrop of incrementalism, the reforms that were put forward by the Victorian State Government during its recent review of the Local Government Act 1989 (Vic) can be interpreted as an attempt to institutionalise participatory and/or deliberative democracy. The review process commenced in September 2015 under the premise that it was 'an important conversation between councils, the community and the Victorian Government about what local government should be' (Minister for Local Government 2015). It went on to propose legislative reform that targeted the organisational processes for how local government engages with its communities. This can also be understood as an attempt to augment, or modernise, representative democratic practices in that jurisdiction with participatory practices, in line with the ascension of these ideas in the theoretical and public 
policy literatures. This article provides a case study analysis of the attempt to legislate deliberative engagement and the barriers that were identified through this process for embedding this practice in the local government sector.

The analysis draws on a number of data sources, including the literature that the Victorian state government published and commissioned; the 562 submissions that were made by various stakeholders throughout the three stages of engagement; and finally, a broad scan of relevant events and actors that were advocating for deliberative democracy during the Review period. To add further focus, whilst the Victorian Local Government Act Review covered a number of issues that might be considered aligned to 'renewing democracy', for example electoral processes and the responsibilities of elected representatives, our analysis focused only on references to deliberative, participatory or community engagement made in the literature and submissions.

As a case study, we do not discuss theories of deliberative democracy extensively; rather, the reform process presents a unique opportunity to inquire into how local government reform might attempt democratic innovation and the limits of taking a legislative reform approach. It provides an account of the barriers that were flagged by the local government sector regarding embedding deliberative engagement in strategic planning processes and identifies considerations that need to bemade. It also makes a contribution to the literature regarding embedding the practice.

This discussion itself is structured in five main sections. It begins by focusing on the Victorian Local Government Act Review and describing the review process as well as the directions proposed. It then establishes a context for this reform, including the events and actors that are likely to have influenced state government. Following this, it examines the key issues that emerged from the submissions made to the Review, in particular the aversion to deliberative reform by the local government sector. It then analyses these issues in order to identify the contextual and capacity considerations that, we argue, need to be addressed for embedding the practice in local government institutions, namely creating shared understanding and consensus around how participatory and deliberative practices are developed, and giving due consideration to the organisational capacity for local government to implement these new ways of working. 


\section{Victorian Local Government Act Review}

In September 2015 the Victorian government launched its review of the Local Government Act 1989. This Review was described as 'the first comprehensive review of local government in a quarter of a century' (DELWP 2015, p. 6). Since 1989 there had been over 90 amending Acts, resulting in hundreds of additions that meant the Act had grown from what was originally a 136-page document to one of over 450 pages (Blacher 2015, p. 2).

The process of reviewing the Act was extensive over a four-year period. Figure 1 marks the major milestones therein:

Figure 1 Review of Local Government Act 1989 (Vic): Milestones

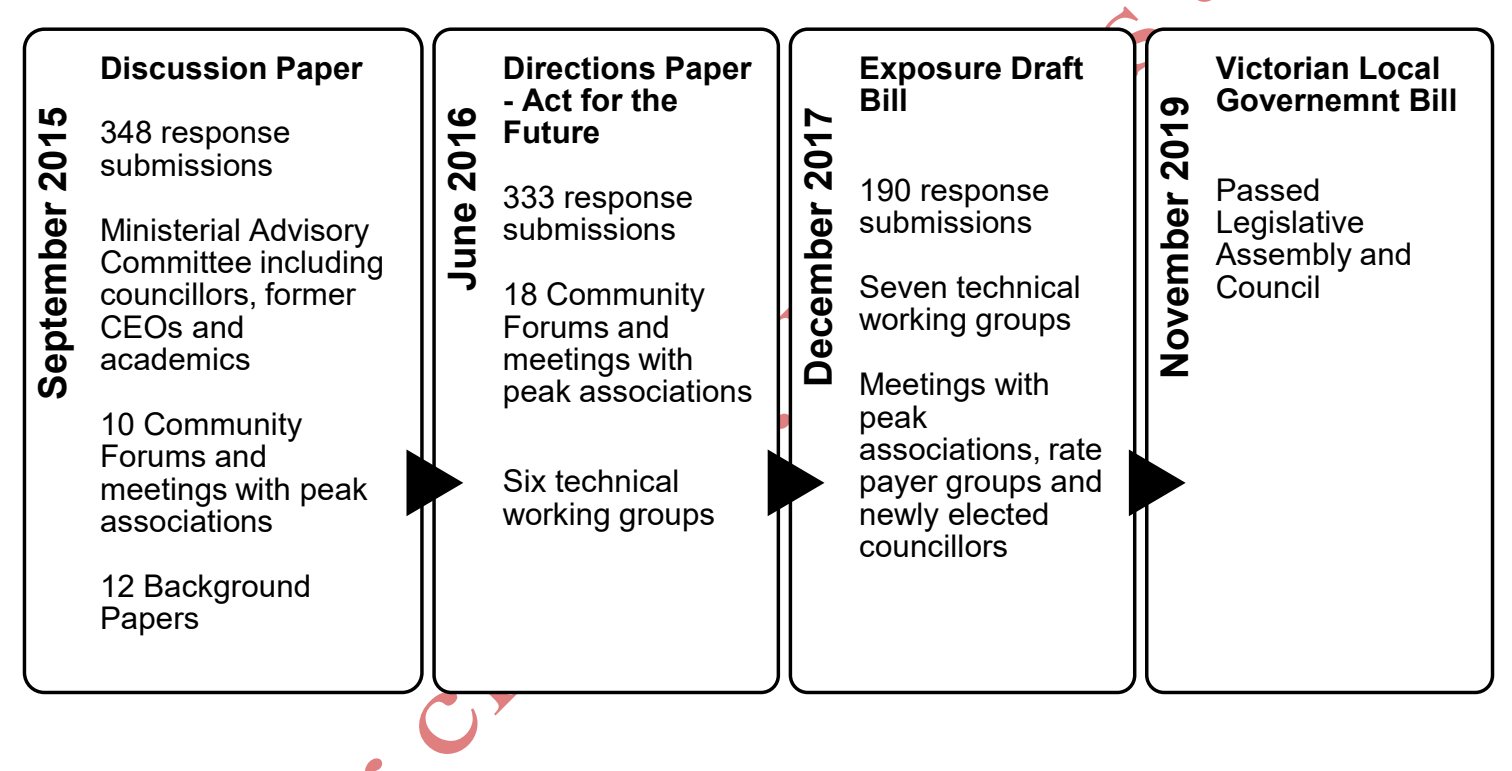

Examining Figure 1, prima facie it may appear that for a state government to dedicate four years to a process of inquiry and reform to its local government sector is overtly rigorous. However, this is by no means unusual in Australia (see, for instance, Grant and Drew 2017 on recent reforms in NSW; see also the 'Final Report' of the Western Australian Local Government Association's (WALGA's) four-year process in that jurisdiction (WALGA 2008) and Dollery, Ho and Alin's (2008) criticisms of the Queensland state government's 18month reform process in 2007-08). In short, due to the nature of local government reform being intrinsically concerned with political reorganisation, for the most part it is highly vexatious (see Dollery and Tiley 2015; Ryan et al. 2016) and as such usually subject to processes of 'appreciative inquiry', then reform (see Grant, Ryan and Lawrie 2015). 
Returning to Figure 1, to begin the review process the Minister for Local Government announced the publication of a 'Discussion Paper' (2015) and appointed an advisory committee made up of councillors, former CEOs and academics. Over the next four-year period, consultation for the review was marked by the publication of three further key documents that aligned to the next stages of consultation: a 'Directions Paper' (2016) and an 'Exposure Draft Bill' (2017) and the final 'Local Government Bill' (2019). Alongside these artefacts, the Local Government Act Review webpage indicates that there were 871 submissions made in response to the first three documents. In addition to these documents, Local Government Victoria (LGV) also commissioned 12 background papers examining different elements of local government (see DELWP 2016 'Appendix 6 Commissioned research of the Discussion Paper') alongside establishing six technical working groups (see DELWP 2016 'Appendix 4 Technical Working Group Members of the Discussion Paper') and held several community forums around Victoria.

Despite this quantity of investigative and appreciative inquiry and policy formulation, the key proposals for reform through the Directions Paper (2016) and the final Local Government (2019) can be represented in Table 1, alongside the stipulations in the extant Act.

Table 1 Key changes proposed as part of the Review

\begin{tabular}{|c|c|c|}
\hline $\begin{array}{l}\text { Current } 1989 \text { Local } \\
\text { Government Act }\end{array}$ & $\begin{array}{l}\text { Proposed in Directions Paper - } \\
\text { Direction Number }\end{array}$ & Local Government Bill \\
\hline $\begin{array}{l}208 \mathrm{~B}(\mathrm{e}) \text { a Council must develop a } \\
\text { program of regular consultation } \\
\text { with its community in relation to } \\
\text { the services it provides. }\end{array}$ & $\begin{array}{l}\text { 46. Require a council to prepare a } \\
\text { community consultation and } \\
\text { engagement policy early in its } \\
\text { term to inform the four-year } \\
\text { council plan and ten-year } \\
\text { community plan }\end{array}$ & $\begin{array}{l}\text { 54 Community engagement policy } \\
\text { Council must adopt and maintain } \\
\text { a community engagement policy } \\
\text { which must; give effect to the } \\
\text { community engagement } \\
\text { principles; and be capable of } \\
\text { being applied in relation to any of } \\
\text { the Council's strategic planning or } \\
\text { policy development; include } \\
\text { deliberative engagement practices } \\
\text { capable of being applied to the } \\
\text { development of the Community } \\
\text { Vision, Council Plan, Financial }\end{array}$ \\
\hline
\end{tabular}




\begin{tabular}{|c|c|c|}
\hline & & $\begin{array}{l}\text { Plan and Asset Plan (emphasis } \\
\text { added) }\end{array}$ \\
\hline $\begin{array}{l}223 \text { Right to make a submission } \\
\text { Council must publish a public } \\
\text { notice specifying details of its } \\
\text { indented Plan or actions, allowing } \\
\text { not less than } 28 \text { days for public } \\
\text { submissions on the matter (either } \\
\text { in person or by proxy). The Act } \\
\text { says Council must consider all the } \\
\text { submissions made and notify each } \\
\text { person who made a submission of } \\
\text { the decision and reasons for that } \\
\text { decision. }\end{array}$ & $\begin{array}{l}\text { 48. Include in regulations that an } \\
\text { engagement strategy must ensure: } \\
\text { the community informs the } \\
\text { engagement process; the } \\
\text { community is given adequate } \\
\text { information to participate; the } \\
\text { scope/remit of the consultation } \\
\text { and areas subject to influence are } \\
\text { clear; those engaged are } \\
\text { representative of the council's } \\
\text { demographic profile. }\end{array}$ & $\begin{array}{l}56 \text { The community engagement } \\
\text { principles } \\
\text { Participants in community } \\
\text { engagement must have access to } \\
\text { objective, relevant and timely } \\
\text { information to inform their } \\
\text { participation; they must be } \\
\text { representative of the persons and } \\
\text { groups affected by the matter; } \\
\text { they are entitled to support to } \\
\text { enable meaningful and informed } \\
\text { engagement; and are informed of } \\
\text { the ways in which the community } \\
\text { engagement process will influence } \\
\text { Council decision making. }\end{array}$ \\
\hline $\begin{array}{l}125 \text { (3) A person has a right to } \\
\text { make a submission under section } \\
223 \text { on the proposed Council Plan }\end{array}$ & $\begin{array}{l}\text { 47. Require a council to conduct a } \\
\text { deliberative community } \\
\text { engagement process to prepare its } \\
\text { Council Plan and to demonstrate } \\
\text { how the Plan reflects the } \\
\text { outcomes of the community } \\
\text { engagement process (emphasis } \\
\text { added) }\end{array}$ & $\begin{array}{l}90 \text { A council must prepare and } \\
\text { adopt a Council Plan of at least } \\
\text { the next } 4 \text { financial years after a } \\
\text { general election in accordance } \\
\text { with its deliberative engagement } \\
\text { practices (emphasis added). }\end{array}$ \\
\hline
\end{tabular}

Source: Victorian Local Government Act 1989, DELWP 2016 and Parliament of Victoria (2019).

Examining Table 1 (at left) it demonstrates that the existing Victorian Local Government Act 1989 has limited requirements for community engagement, particularly compared with its counterpart legislation in NSW, Western Australia and (to a lesser extent) South Australia and Tasmania (for an account see Grant and Drew 2017). Nevertheless, the Local Government (Best Value Principles) 1999 (\$208B(e)) amendment required that each council 'develop a program of regular consultation with its community in relation to the services it provides'; however overall, community engagement is implied rather than explicit and the Act provides little guidance as to how this consultation might be conducted. The only prescriptive requirement is Section 223 which requires councils to ensure community 
members have an opportunity to make submissions regarding the proposed council plan and budget.

Moving to the Directions Paper stage of Table 1, it is clear that, beyond consultation, there has been an expectation that community members directly participate in council decisionmaking in a number of proposals. Of the ten major reform directions proposed in the Directors Paper, six had a stated aim of 'Revitalising Local Democracy'. Amongst these was the suggestion that 'deliberative community engagement' be used for the development of key council strategic plans, including the Council Plan and Budget. Following consultation, 'deliberative community engagement' was removed from the 2017 Draft Exposure Bill, However, however it was then re-introduced in the final Local Government Bill with the slightly adapted terminology of 'deliberative engagement practices'. We can therefore assume that the state government is driving a reform agenda around increasing community engaged practice in the local government sector.

\section{Context-dependent impetus for deliberative reforms}

In addition to the broader context for this reform direction, it is informative to briefly capture the events and actors that are likely to have influenced state government's direction in order to fully understand the reform environment. In its media release on 17 November 2016 'Council Plan Changes Puts Residents First', the Minister stated that as 'its first major decision as part of the reform of the Local Government Act' councils would 'by law' develop four-year plans with their communities (Minister for Local Government 2016). It noted that current requirements for consultation were limited and that the state government wanted councils to 'involve eommunities from the start through tools like citizens' juries or community panels'. In this media release, the need for these measures was clearly framed as something that was in response to community advocacy.

This framing aligns with results from the annual Local Government Community Satisfaction Survey, which has consistently produced low scores on indicators of good governance and political participation. For instance, the indicator 'making decisions in the interest of the community' has been one of the weakest areas of council performance since it began to be measured in 2014 (DELWP 2019). This is also noted in the 2015 Discussion Paper, which states 'an issue often raised in correspondence to the minister is frustration about levels of consultation and engagement with communities by councils about key decisions' (DELWP 2015, p.15). The Discussion Paper questioned whether 'the Act currently 
contains strong enough provisions about community consultation ... and if alternative approaches to improving engagement and feedback should be mandated in legislation' (DELWP 2015, p.52). At the Directions Paper (2016) stage, the community satisfaction survey results were mentioned in direct relation to deliberative engagement, highlighting that Councils which had adopted deliberative engagement processes had, in several instances, shown better scores for community satisfaction surveys (DELWP 2016, p.28).

In stark comparison to the poor results for community engagement in the Community Satisfaction survey, only months before the publication of the Discussion Paper, the City of Melbourne won both the International Association for Public Participation (IAP2) Australasian and International Organisation of the Year. As a speaker at the Future of Local Government Summit in May 2015, Cr Stephen Mayne noted that Melbourne's participatory budget project, the 'People's Panel', had been 'instrumental' to winning those awards. Research conducted of the People's Panel found that 100 per cent of panel members expressed support for more citizen involvement in the policymaking process, and in addition, that they had 'increased levels of trust and confidence in the council and a higher general satisfaction with the outlook for the city' (Reece 2015, p. 196). Whilst deliberative engagement wasn't explicitly noted in the 'Discussion Paper', the City of Melbourne's 'People's Panel' was included as a case study and proposes: 'there may be potential to formalise in the Act the involvement of citizens' bodies like the City of Melbourne in the framing of certain major policy decisíons of council' (DELWP 2015, p. 53).

Both the peak sector/organisations for local government in Victoria, the Municipal Association Victoria (MAV) and Victorian Local Government Association (VLGA) have consistently supported deliberative engagement practice. At MAV's (2015) 'Future of Local Government Summit' almost every key speaker discussed deliberative engagement projects, including what is arguably Australia's most high-profile deliberative democracy advocacy organisation, the newDemocracy Foundation. The VLGA has also advocated for deliberative engagement, in its submission to the 2015 Discussion Paper it stated 'the Act should provide the ability for local government to establish not only committees but Local Government Boards, Citizens Panels and like forums, enhancing participatory democracy by allowing for processes which give local community members an avenue for actively expressing their views and helping shape policies and final outcomes (VLGA 2015, p. 11).

This discussion demonstrates that there was a combination of reasons for the embracing of participatory and deliberative processes as part of the review of the Act, including 
community dissatisfaction, ensuring local governments are accountable and responsive to their local communities further fuelled by the advocacy for deliberative practice by both key government and private sector actors.

\section{Local Government Act Review (2015-17) submissions}

All submissions that either made direct reference to deliberative engagement, or more broadly, community engagement, were considered. The number of submissions can be found in Table 2.

Table 2 Responses that noted deliberative or community engagement

\begin{tabular}{|c|c|c|c|}
\hline & $\begin{array}{l}2015 \text { Discussion } \\
\text { Paper }\end{array}$ & $\begin{array}{l}2016 \text { Directions } \\
\text { Paper }\end{array}$ & $\begin{array}{l}2017 \text { Exposure } \\
\text { Draft }\end{array}$ \\
\hline Council & 31 & 69 & 47 \\
\hline Sector organisations (VLGA, MAV; LGPro) & 3 & & 3 \\
\hline Councillors & 3 & 9 & 1 \\
\hline Individuals & 33 & 24 & 7 \\
\hline Community organisations & & 19 & 12 \\
\hline Private & 4 & 8 & 3 \\
\hline Total & 85 & 132 & 73 \\
\hline$\%$ Total submissions & $42 \%$ & $74 \%$ & $40 \%$ \\
\hline
\end{tabular}

Source: Compiled from DELWP 2015; DELWP 2016; DELWP 2017.

As Table 2 demonstrates, the 2016 'Directions Paper' received the highest number of submissions that referred to either deliberative or community engagement ${ }^{1}$. A review of all the submissions reveals some key themes regarding the implementation of deliberative engagement practice or more expanded community engagement. We consider these in turn.

\section{Community engagement and non-local government respondents}

Groups considered 'Non-Local Government Sector' include private individuals and community organisations. At the 2015 'Discussion Paper' stage, non-local government submissions that mentioned community engagement fell into three broad categories: Those that thought there was a need for greater community involvement in decision-making 
(n.29=60\%); those that advocated for more transparency and accountability regarding decision-making (n. $19=39.5 \%$ ) and those that thought the executive of councils have too much influence over decision-making (n.19=39.5\%). Responses to the 2016 'Directions Paper' had similar results, with those respondents who thought there was a need for greater community involvement in decision-making (n.28=55\%) and those that advocated for more transparency and accountability regarding decision-making (n.19=37\%). There was a considerable decline in the number of submissions that referred to the executive having too much influence (n.4=8\%) and a greater number of submissions that did not support deliberative engagement and citizens' juries as a form of engagement (n. $5=10 \%$ )

Although there were far fewer submissions in this category that referenced community engagement at the 2017 Exposure Draft stage (n.22) a higher percentage thought there was a need for greater community involvement in decision-making than the draft Bill proposed (n.16=72\%). Amongst these, the majority wanted to see the measure strengthened, with very few referring to transparency and accountability (n. $2=9 \%$ ).

\section{Community engagement and local government sector}

Groups considered 'Local Government Sector' included councils, sector organisations (such as LGPro and MAV) and councillors. At the 2015 'Discussion Paper' stage, responses from the local government sector referring to deliberative or community engagement were relatively limited. The responses mostly fell into two categories: Those that noted that community engagement should not be prescriptive (n.22=59\%) and a few that noted that as elected representatives Councillors are already accountable to their communities (n. $8=21 \%$ ). However, the issues of deliberative or community engagement became much more prominent in responses from Local Government Sector at the 2016 Directions Paper stage, where 69 of the 72 Councils, or $95.8 \%$, of those that responded commenting on the requirement for deliberative engagement. Of those, key issues that emerged included:

\begin{tabular}{|l|l|}
\hline Noting that deliberative engagement should not be prescriptive & 50 \\
\hline Noting that there needs to be clarification around what is meant by 'deliberative' & 34 \\
\hline $\begin{array}{l}\text { Noting that as elected representatives (councillors) are already accountable to their } \\
\text { communities }\end{array}$ & 25 \\
\hline Voicing concern regarding resources required for deliberative engagement & 23 \\
\hline
\end{tabular}


At the 2017 'Exposure Draft' stage, the key points that the local government sector made were:

\begin{tabular}{|l|l|}
\hline Support for community engagement measures & 16 \\
\hline Asked for more clarity around regulation and potential guidelines for engagement & 20 \\
\hline Listed issues of resources and timelines & 19 \\
\hline
\end{tabular}

Based on the submissions the themes that will now be considered in terms of how the expressed views in the submissions align with the proposed directions of the new Local Government Act include: Understanding the community and their expectations when they are involved in decision-making; the lack of consensus by the sector for embedding deliberative engagement practice and their organisational capacity to do so.

\section{Community involvement in decision-making}

As noted earlier, the understanding that 'community wanted more say' in council planning was a common theme in the Local Government Act Review process; it was prevalent in the literature published and commissioned by state government (see, for instance, Minister for Local Government 2016 and QDOS Research 2016) and it was identified as a key issue when looking at the non-local government sector submissions. This section examines both the submissions and the justifications in more detail.

Beginning with the submissions, whilst the majority of non-local government sector submissions advocated for greater community involvement in decision-making, closer analysis of the actual submissions tells a more nuanced story. At the 2015 Discussion Paper stage, over a half $(53 \%)$ contextualised their desire to become more involved in decisionmaking in order to influence urban planning decisions they disagreed with. One such example stated:

With the growing urbanisation of Melbourne and its surrounds and the increasing threat of climate change, it has become increasingly important that local government provide citizens with opportunities to participate in the planning discussions and debates affecting their neighbourhood (Response 147 Discussion Paper 2015).

At the 2016 'Directions Paper' stage this percentage dropped to 32\%; however it was still significant. Community submissions spoke of 'over-development' and not being consulted on infrastructure projects, many of which related to concerns around higher-density living and 
urban sprawl. In Victoria, the state government has final authority on urban planning matters, and therefore, a deliberative engagement process would not necessarily empower citizens to stop a development project they object to. This tension is demonstrated in the experience of Auckland were the creation of local boards, which were intended to strengthen integration of community actors in planning activities, did not sit comfortably with the existing formal institutional arrangements and generally reproduced many of the same issues of territorial fragmentation that characterised Auckland's previous local government arrangements (McFarlane et al. 2015, p. 466).

Perhaps ironically, one of the reports that the State Government chose to reference in its Discussion Paper (2015) cautions against engagement processes that imply authority around decisions which may not be founded: 'The reality is that many local issues require a state or commonwealth response, and councils might facilitate this planning process but are not solely responsible for realising the objectives set by communities (Tan \& Artist 2013, p. 12). This consideration is not evident in any of the review documents or proposals, despite it being clear it is a latent risk in pursuing more participatory governance processes (see, for instance, Christensen and Grant 2016).

Although there were community submissions that focused directly on having more community involvement in decision-making, a great deal of these contextualised this around a need for greater transparency. There were a number of submissions at both the 'Discussion Paper' (2015) and 'Directions Paper' (2016) stages which argued that council meeting procedures limited the community's ability to inform council decision-making. As a way to address this perceived lack of transparency, community members' suggestions were focused on initiatives that made interactions with council, and their decision-making, easier to access. Initiatives that were proposed included more accessible procedures for question-time, the publication of records demonstrating how individual councillors voted, and making recordings of meetings accessible to the public. For this group of submissions, the issue is having what they see as fair and open process for council decision-making. This highlights the need for more clarity around what community is actually referring to when it advocates for involvement in decision-making. This also needs to be balanced with a deeper understanding of the community's motivation to engage in deliberative processes.

Some council submissions to the ensuing 'Directions Paper' (2016) noted this as an issue, predicting that 'regular participants' will engage with a deliberative engagement process, but the majority of the community would not actively participate (Stonnington City 
Council 2016). Several, including that of the Municipal Association of Victoria (MAV) cautioned against the 'consultation fatigue' communities would experience should this level of engagement be legislated for. In fact, the issue of community disengagement was recognised by the state government in the 2015 'Discussion Paper' where it conceded that some councils consistently receive low numbers of submissions in response to strategic documents despite their best efforts to engage communities (DELWP 2015, p. 52).

Juxtaposed to this, participatory governance processes inevitably require far higher degrees of citizen involvement and time. As Fung and Wright (2003, p. 33) have found, 'empowered participation may demand unrealistically high levels of popular commitment, especially in contemporary climates of civic and political disengagement'. Given the state government's proposed alternative for community engagement requires far higher levels of participation by community members, they must assume that communities will be more willing to engage with council's strategic planning if they are given increased authority around decision-making.

The community research that the state government commissioned to inform the Local Government Act Review indicates that this assumption may be problematical. QDOS Research (2016, p. 20) found that across the focus groups there was a belief that individuals cannot influence the system, participants expressed that they didn't care enough, or didn't know enough to get involved, others expressed they had become so disillusioned by council that they had stopped paying attention to it. Scholarly inquiry has also found that much local participation occurs when communities are mobilised around matters in which they have an immediate interest (Copus 2003, p.36). This can be seen in both the submissions to the Review and the QDOS Research (2016) survey. Further to this, research related to New Zealand's Local Government Act 2002 suggested that requiring community engagement from an already over-burdened society may result in predominantly extremist views being represented (Brosnan and Cheyne 2010, p. 33). A related consideration is that there was negligible reference to how 'deliberative engagement practices' will engage traditional owners and more marginalised communities throughout the Review process. In an environment with low engagement, councils are likely to find it hard to engage the disenfranchised even with the lure of having more authority over decision-making. What is required is a clearer understanding of how community actually wants to be engaged. 


\section{Consensus around deliberative engagement}

The local government sector's response to proposals for deliberative engagement can be broadly characterised as antipathetic. Although supportive of community engagement, many councils argued that how strategic plans are developed, and the degree to which the community is involved, should not be prescribed in legislation. This was particularly evident at the 2016 'Directions Paper' stage, where 72 per cent of council submissions made this point (n.50). At this point, the main contentions of councils were that there needed to be further clarification of what state government intended by 'deliberative engagement' since there was no definition or explanation provided (n.34=49\%); and that councils were already sufficiently accountable to their communities and involving them in decision-making (n.25=36\%). This section will explore each of these themes, with regard to existing literature where appropriate, in order to better understand the implications for implementation of this type of reform.

To begin, the ambiguity of terminology around 'deliberative engagement' and what exactly was implied was highlighted by a number of councils and other sector organisations. This included International Association for Public Participation (IAP2) ${ }^{2}$ Australia, which flagged in their response to the 2016 'Directions Paper', that the term 'deliberative' may not be well understood by many in the state and local government sectors (IAP2 2016). In their 2016 Directions Paper submission, Local Government Professionals (LGPro), one of the peak membership associations in Victoria, noted that they 'have concerns with the terminology of 'deliberative' engagement as a requirement of the Act, and a query as to what the evidence that the quality of engagement would be enhanced by the Act being so prescriptive in this regard' (LGPro 2016).

The reasons offered for why 'deliberative engagement' should not be prescribed varied. Mostly submissions noted that each individual council should tailor engagement practice according to their unique communities and contexts. For instance, in its submission to the 2016 Directions Paper, Greater Bendigo (2016) stated: 'The methodology [for community engagement] should be determined by the council in accordance with local expectation and accountability, not prescribed in regulation'. Similarly, Central Goldfields (2016) asserted: 'Council supports optimum community engagement, and believes that council is best placed to determine how such engagement takes place, rather that it be prescribed'. For its part, Hindmarsh Shire (2016) stated: 
Deliberative practices need to be appropriate and fit-for-purpose for the community they are applied to. One size does not fit all'.

Most councils argued that they were already sufficiently delivering on community engagement practice, some highlighting that elected representatives were ultimately accountable to their constituents. In their submission, the MAV (2016) made a point of noting 'Councillors are elected representatives. They should engage with the community through a variety of mechanisms to assist them to inform themselves and to perform their role' otherwise stated, framing deliberative engagement as a means to better informing decisionmaking, but at the same time making it clear that the authority remains with elected representatives. In fact, Copus (2003, p. 33) noted that this type of 'reformistagenda ignores the attitudes councillors hold about political representation, their own roles as representatives and about the whole business of citizen participation'.

Arguably, the merits or flaws of arguments about 'deliberative' engagement and whether it is prescribed or not are less important than the fact that the sector has responded with this level of resistance. Johnson (2009, p. 681) found that deliberative empowerment at the institutional level is largely determined not by the features of a given deliberative democratic model but by the broader political context, especially elite-actor motivation and their commitment to sharing decision-making power. Policymakers must be willing to incorporate into their decisions the outputs of deliberation. They must be willing to transfer at least some decision-making powyer to deliberative participants (Johnson 2009, p. 699). This is supported by other research that finds when the processes are initiated by government or when policymakers explicitly support them, the decisions of deliberative process are more likely to be implemented (Caluwaerts \& Reuchamps 2016, p. 15).

Without some consensus from the local government sector, there is a possibility that the legislation would be implemented as a matter of compliance rather than a sector-driven commitment to increase the devolution of decision-making power to communities. In the example of the United Kingdom's Local Government Act 2000, scholars found that 'in the absence of a clear articulation of democratic priorities and values' practices have emerged that instead of shifting deeply embedded institutional norms have instead been adapted to reinforce institutional priorities and values' (Pratchett 2004, p. 372). Similarly, reviews of New Zealand's Local Government Act 2002 found that its implementation was hindered by the need for capacity building in councils to interpret and apply its provisions (Brosnan and Cheyne 2010, p. 30). For her part, Lowndes (2005, p. 296) describes this as 'institutional 
stickiness' where, despite legislation, government guidance and the widespread adoption by councils of model constitutions, the rules-in-use (as opposed to the rules-in-form) do not seem terribly different to those that went before. Likewise, in Scotland which experienced similar reform with Community Planning, 'local authorities have been encouraged and then required, to change their arrangements for political leadership and decision-making. But they have for the most part insisted on driving the new vehicle down the old path-whatever the discomfort involved!' (Lowndes 2005, p. 297).

A previous study of Victorian councils which investigated how community consultation is practiced found that 'in the absence of clear guidelines councils are wary of devolving power' (Brackertz and Meredyth 2009, p. 153). Given the general ambivalence that has been shown towards deliberative engagement by the local government sector in Victoria so far, without a concerted approach to finding common understandings and shared commitment to change, reforms are likely to be met with the same 'institutionat stickiness' Lowndes (2005) described.

\section{Capacity of local government sector}

One of the main issues the local government sector raised about having to deliver deliberative engagement processes for all strategic documents was that councils did not have the resources required to undertake such processes, particularly in a rate-capped environment. For instance. in their submission to the Discussion Paper (2015) MAV highlighted that the mandating of specific, additional platforms or processes for community engagement, in the absence of understanding the efficacy, costs and the capacity of the council to resource such platforms or processes, is not supported (MAV 2016). LGPro made a similar statement and IAP2 Australia flagged that it is 'highly possible that many Victorian Councils do not have the resources to undertake a quality deliberative process' (IAP2 Australia 2017).

The issue of resourcing was particularly highlighted by rural councils. The VLGA commented that 'the resource constraints faced by rural shire councils in particular must be considered leading up to and during the implementation of the Bill' (VLGA 2017). The fact that a Melbourne City Council initiative was proposed as a case study example in the 2015 Discussion Paper and then implied as an aspirational 'standard' in the 2016 Directions Paper was challenged by a number of submissions who noted that the resourcing available for a capital city council is far greater than others. Bherer (2010, p. 288) found that, except for town hall meetings, participatory arrangements are developed in municipalities with greater resources, that is, those with fairly large populations. 
In addition to the resource limitations, there needs to be consideration of the actual capabilities in local government to deliver deliberative engagement processes. As Hendricks and Carson (2008, p. 293) noted, 'deliberative ideals have become commercial goods bought and sold in an expanding consultancy market'. Some submissions articulated that conducting a deliberative process was a particular skill that they would need to engage external consultants to deliver. Even though it is not possible to expand upon here, it is interesting that they did not make the same conclusions regarding expanded community engagement. Clearly, there is a sense in the Victorian local government sector that 'deliberative engagement' requires a specific skill set, beyond those of community engagement, and requiring external support. Regardless of whether this is true, City of Port Phillip made a reasonable point when they flagged that the proposed legislation would/mean that 79 councils across Victoria would be seeking the same 'deliberative engagement'expertise over the same period of time during the development of the Council Plan, they noted that, therefore, access to such expertise would be problematic (City of Port Phillip 2017). These points demonstrate that, to be effective, the proposed legislation must be accompanied by clearer guidelines and capacity-building initiatives, particularly in the early transition period when councils are reviewing and establishing new organisational systems and procedures to meet their legislated requirements.

\section{Discussion}

As seen through the key themes that emerged from submissions made during the entire review process, the implementation phase of the new Victorian Local Government Act will need to make a number of considerations. We discuss these in turn.

\section{Input and oufput-orientated legitimacy}

As Sullivan $(2009$, p.65) argued, participatory governance policies 'are themselves subversive acts, designed with the express purpose of unsettling the established relationships of politicians, the public and professionals in the pursuit of new ones'. With its focus on deliberative engagement and the increased participation of community in strategic planning, the Victorian state government has favoured one such 'subversive' approach and designed an approach that increases input legitimacy over output. Input legitimacy is structured around access to the political process and enhancing public participation to influence policy-making; instead, output legitimacy considers policy-making as problem solving in the interest of the general public, it is therefore derived from the expertise of policy makers and subject experts 
(Abels 2007; Caluwaerts \& Reuchamps 2016). Arguably, legitimacy requires the development of both input-oriented and output-oriented means, of both representativeness and responsiveness (Sommerville 2005, p.124). The proposed reform to the Local Government Act 1989 was input-orientated and therefore did not consider how councils' expertise in policy-making might be enhanced. It makes the assumption that if councils broaden access to policy-making processes they will achieve the desired results. There is an argument to be made for output-oriented means of building capacity of councils' responsiveness that should be explored. Especially in the context of the themes found in both the community submissions to the Review process as well as those by the local government sector. Participatory procedures do not per se improve the democratic legitimacy and accountability of policy-making. In order to do so, their linkage to the pølitical system has to be reconsidered and improved - empirically as well as conceptually (Abels 2007, p. 103).

\section{Embedded practice}

In the Exposure Draft (2017) of the legislation, the state government has taken a more normative approach and set out requirements for 'collaboration' and enhanced community engagement, rather than the more prescriptive approach of 'deliberative engagement' it took in the 2016 Directions Paper. Related to the previous point around output-orientated approaches, and connected to the local government sector submissions to the Review, this normative approach may assume that local government has both the inclination and capacity to implement the change proposed.This assumption does not consider existing practice and norms which may be difficult to shift. Even when deliberative engagement activities are implemented, as noted earlier, research has found that without the explicit support of policymakers, and a degree of 'institutional embeddedness', the decisions made through deliberative processes are unlikely to be accepted or implemented (Caluwaerts \& Reuchamps 2016, p. 15). Consultation with local government practitioners in Australia found that 'many councils remain wedded to a more or less rigid application of representative democracy, with little interest in considering more participative practices and community-led arrangements' (Sansom and Robinson 2019, p. 8). As such, without a genuine commitment from councils, how more participatory practice is applied and embedded in the local government sector is considerably uncertain. This is especially true in a context where there is such ambiguity around the expectations of state government. It is possible that councils will develop policies and procedures which ultimately are only partly implemented, or not fully applied, as the state government intended through the legislation. 
Approaches to implementation need to consider not only the required changes but also the equally important, but rarely recognised, task of de-institutionalising old ways of working (Lowndes and Sullivan 2004, p. 67). The agency of individual actors within local government organisations, and their influence over how the legislation is not only implemented but also how it is understood is significant. These actors operate within these new expectations, but they are not passive participants, they also influence how the rules themselves are interpreted, adapted and ultimately how they evolve over time (Lowndes 2005, p. 293). This is seen in the Victorian Auditor General's 2017 Audit Public Participation and Community Engagement: Local Government Sector where it found that the councils audited typically had strong public participation frameworks however they did not routinely apply them and there was considerable variation in their implementation (VAGO 2017, p. viii). It is conceivable that whilst new procedures and community engagement policies will be dutifully produced by local government organisations, that their application will be hindered by existing organisational cultures and ways of working. New rules mayexist in name only while the old rules retain their hold at an informal, but no less effective, level. Elinor Ostrom (1990) recognises this important distinction in her contrast between rules-in-use and rules-in-form (Lowndes 2005, p. 294).

The VLGA (2015) submission to the 2015 Discussion Paper referred to this potential issue of implementation, also noting that legislation can influence, but cannot by itself deliver community engagement by localgovernment. They argued that to be effective, legislation must be complemented by robust policy frameworks and other practical supports. So far, the state government has provided little guidance to how it will support councils in this regard. Without further consultation and engagement with the local government sector itself, this reform agenda may not be fully realised.

\section{Conclusion}

This case study provides insights into some of the key issues of implementation for deliberative engagement through the prism of the submissions for reform of the Victorian Local Government Act 1989 and more generally. It has revealed the need for a deeper understanding of the issues that underpin community dissatisfaction with council decisionmaking to better understand how participatory practice aligns with the expectations of community, especially with regard to greater transparency. This would consequently provide greater insight into whether deliberative engagement would in fact resolve these issues, and 
importantly, whether it is realistic to assume that community will participate in such extensive engagement processes. Also, consideration needs to be given to the authorising environments (Moore 1995) within which local government operates. Likewise, greater collaboration with the local government sector would have been useful. This would have ensured that the legislation was founded on a common understanding of the rationale for deliberative engagement, and furthermore established some consensus about how it might be applied.

While participatory practice and deliberative engagement are clearly in the eyesight of Victorian broader democratic reform, there are authorising environments and operational capacity that needs to be considered. We suggest that in order to catalyse change in the local government sector, more consideration needs to be given to firstly, the reasons underpinning community dissatisfaction, secondly creating shared understanding and consensus for what sort of practices need to emerge and finally, giving due consideration of the organisational capacity of local government to implement these new ways bf working.

\section{Endnotes}

${ }^{1}$ However, this should consider that the format for the submissions was a 'tick-a-box' document and of the 132 responses, 21 ticked that they supported the deliberative engagement requirements yet did not provide any commentary. The fact that there were a series of questions proposing deliberative engagement (10 in total) may also account for the larger number of submissions that noted it.

${ }^{2}$ IAP2 is an international member association which seeks to promote and improve the practice of public participation or community and stakeholder engagement. It describes itself as 'a peak body for engagement' practice https://www.iap2.org.au 


\section{References}

Abels, G. (2007). Citizen involvement in public policy-making: Does it improve democratic legitimacy and accountability? The case of pTA. Interdisciplinary Information Sciences, 13(1), 103-116.

Bherer, L. (2010). Successful and Unsuccessful Participatory Arrangements: Why is there a participatory movement at the local level?. Journal of Urban Affairs, 32(3), 287-303.

Blacher, Y. (2015). Local Government Act Review: Imagining Local Government in the 21 st Century.

Brackertz, N., \& Meredyth, D. (2009). Community Consultation in Victorian Local Government: a Case of Mixing Metaphors?. Australian Journal of Public Administration, 68(2), 152-166.

Brosnan, B., \& Cheyne, C. (2010). Stronger communities? Changing prospects for community-led strategic planning in New Zealand. Commonwealth Journal of Local Governance, 7, 22-44.

Caluwaerts, D., \& Reuchamps, M. (2016). Generating Democratic Legitimacy through Deliberative Innovations: The Role of Embeddedness and Disruptiveness. Representation, 52(1), 13-27.

Christensen, H., \& Grant, B. (2016). Participatory Budgeting in Australian Local Government: An Initial Assessment and Critical Issues. Australian Journal of Public Administration, 75(4), 457-475.

Christensen, H., \& Grant, B. (2019). Outsourcing local democracy? Evidence for and implications of the commercialisation of community engagement in Australian local government. Australian Journal of Political Science, 1-18.

Christensen, H. (2018). Legislating community engagement at the Australian local government level. Commonwealth Journal of Local Governance. Issue 21: 6515

Christensen, H. (2019). Preliminary Findings - Local Government Community Engagement Census

$\underline{\text { https://communityengagementresearch.com.au/?page } \mathrm{id}=81}$

Copus, C. (2003). Re-Engaging Citizens and Councils: The Importance of the Councillor to Enhanced Citizen Involvement. Local Government Studies, 29(2), 32-51. 
Curato, N., Dryzek, J. S., Ercan, S. A., Hendriks, C. M., \& Niemeyer, S. (2017). Twelve key findings in deliberative democracy research. Daedalus, 146(3), 28-38.

Department of Environment, Land, Water and Planning (DELWP). (2015). Review of the Local Government Act 1989 Discussion Paper, http://web.archive.org/web/20190307201735/https://www.yourcouncilyourcommunity. vic.gov.au/previous-consultation accessed 5 June 2019.

Department of Environment, Land, Water and Planning (DELWP) (2016) Act for the future: Directions for a new Local Government Act, https://www.localgovernment.vic.gov.au/_data/assets/pdf_file/0042/397968/Act_for_t he_Future_-_Directions_for_a_new_Local_Government_Act.pdf accessed 5 June 2019.

Department of Environment, Land, Water and Planning (DELWP) (2017a a A New Local Government Act for Victoria,

https://www.localgovernment.vic.gov.au/__data/assets/pdf file/0023/91139/Narrativefor-A-New-Local-Govt-in-Victoria-FINAL.pdf

Department of Environment, Land, Water and Planning (DELWP) (2017b) Exposure Draft https://www.localgovernment.vic.gov.au/data/assets/pdf_file/0022/91138/LocalGovernment-Bill-Exposure-Draft.pdf

Department of Environment, Land, Water and Planning (DELWP) (2019) Local Government Community Satisfaction Survey: 2018 State Wide Research Report https://www.localgovernment.vic.gov.au/ data/assets/pdf file/0030/325848/Communi ty-Satisfaction-Survey-State-Wide-Research-Report-2018.pdf accessed 5 June 2019

Dollery, B. E., Ho, C.M. \& Alin, J. (2008). No lessons learned: A critique of the Queensland Local Government Reform Commission 'Final Report'. Agenda: A Journal of Policy Analysis and Reform 15(1), 67-84.

Dollery, B. E., \& Tiley, I. (Eds.). (2015). Perspectives on Australian local government reform. Sydney: The Federation Press.

Dryzek, J. (2012). Foundations and frontiers of deliberative governance. Oxford University Press.

Escobar, O. (2013). Transformative practices: the political work of public engagement practitioners, The University of Edinburgh. 
Fishkin, J. (2011). When the people speak: Deliberative democracy and public consultation, Oxford University Press.

Fung, A., \& Wright, E.O. (2003). Deepening democracy: Institutional innovations in empowered participatory governance. Verso.

Goodin, R. (2008). Innovating democracy: Democratic theory and practice after the deliberative turn. OUP Oxford.

Grant, B., \& Drew, J. (2017). Local Government in Australia: History, Theory and Public Policy. Singapore: Springer.

Grant, B., Ryan, R., \& Lawrie, A. (2015). Dirty hands and commissions of inquiry: An examination of the Independent Local Government Review Panel(ILGRP) in NSW, Australia. In Schwatz, M., \& Harris, H. (Eds). Conscience, Leadership and the Problem of 'Dirty Hands' (Research in Ethical Issues in Organizations), Emerald, UK, 19-39.

Hartz-Karp, J., \& Briand, M. (2009). Institutionalising Deliberative Democracy. Journal of Public Affairs, May(9), 125-141.

Hendriks, C. (2012). The politics of public deliberation: Citizen engagement and interest advocacy, Singapore: Springer.

Hendricks, C., \& Carson, L. (2008). Can the market help the forum? Negotiating the commercialisation of deliberative democracy. Policy Sci, 41, 293-313.

IAP2 [International Associationfor Public Participation]. (2019). About us. < https://www.iap2.org.au/about-us/about-iap2-australasia/ > . Consulted 26 November 2019.

Johnson, G. F.(2009). Deliberative Democratic Practices in Canada: An Analysis of Institutional Empowerment in Three Cases. Canadian Journal of Political Science, 42(3) (Sept 2009), 679-703.

Know Your Council website https://knowyourcouncil.vic.gov.au/comparecouncils?service area key $=$ governance $\&$ primary $=16177 \&$ councils $=14813 \&$ councils $=$ $\underline{16265}$

Lowndes, V. (2005). Something Old, Something New, Something Borrowed... How institutions change (and stay the same) in local governance. Policy Studies, 26(3/4). 291-309. 
Lowndes, V., Pratchett, L., \& Stoker, G. (2001). Trends in Public Participation: Part 1 - Local Government Perspectives. Public Administration, 79(1), 205-222.

Lowndes, V., \& Sullivan, H. (2004). Like a horse and carriage or a fish on a bicycle: how well do local partnerships and public participation go together?. Local government Studies, 30(1), 51-73.

Mayne, S. (2015). Presentation at Future of Local Government Conference https://s3-apsoutheast-2.amazonaws.com/ehq-production-australia/ 7aa05ea50976225e7ee45681e4520f5cdfa2e355/documents/attachments/

McFarlane, K., Solomon, R., \& Memon, A. (2015). Designing Institutions for Strategic Spatial Planning: Auckland's Governance Reforms. Urban Policy and Research, 33(4), $452-471$.

Minister for Local Government. (2015). 'Consultation Begins On Local Government Act Review' Department of Premier and Cabinet Media Release 7 September 2015

https://www.premier.vic.gov.au/consultation-begins-on-local-government-act-review/ accessed 14 May 2019.

Minister for Local Government. (2016). 'Council Plan Changes Puts Residents First', Department of Premier and Cabinet Media Release 17 November 2016, https://www.premier.vic.gov.au/council-plan-changes-puts-residents-first/ accessed 14 May 2019.

Moore, M.H. (1995). Creating public value: Strategic management in government. Harvard University Press.

Municipal Assøciation of Victoria (MAV). (2017). Future of Local Government Declaration of Cormmitment https://www.mav.asn.au/what-we-do/sector-development/future-oflocal-government accessed 1 June 2019.

Municipal Association of Victoria (MAV). ( (n.b) Future of Local Government Project https://www.mav.asn.au/what-we-do/sector-development/future-of-local-government accessed 1 June 2019.

newDemocracy (n.d.). Principles. $<$ https://www.newdemocracy.com.au/principles/ $>$. Consulted 26 November 2019. 
Norris, P. (2011). Democratic deficit: Critical citizens revisited. Harvard: Harvard University Press.

Parkinson, J., \& Mansbridge, J. (Eds.) (2012). Deliberative systems: Deliberative democracy at the large scale. Cambridge University Press.

Parliament of Victoria (2019). Local Government Bill 2019 http://www.legislation.vic.gov.au/domino/Web_Notes/LDMS/PubPDocs.nsf/ee665e366 dcb6cb0ca256da400837f6b/489e4f560ddb6f1dca2584b1000e59ed!OpenDocument

Pratchett, L. (2004). Local Autonomy, Local Democracy and the 'New Localism', Political Studies, 52, 358-375.

QDOS Research (2016). Local Government Act 1989 Review Community Attitudes Research

Reece, N. (2015). Australia's 'third bite' at democracy. Meanjin, 74(3),193-198.

Response 147 (2015) Submission to Discussion Paper

https://www.yourcouncilyourcommunity.vic.gov.au/submission?preview=true accessed 20 May 2019.

Ryan, R., Hastings, C., Grant, B., Lawrie, A., Ní Shé, E., \& Wortley, L. (2016). The Australian experience of municipal amalgamation: Asking the citizenry and exploring the implications. Australian Journal of Public Administration 75(3), 373-390.

Sansom, G., \& Robinson, T. (2019).Place-based Governance and Local Democracy: Will Australian Local Government Deliver?, LogoNet, Australia.

Saward, M. (Ed.). (2000). Democratic innovation. London: Taylor \& Francis

Stonnington City Council (2017) Submission 50 to Directions Paper https://www.yourcouncilyourcommunity.vic.gov.au/Directionpapersubmissions accessed 9 June 2019.

Sullivan, H. (2009). Subversive spheres: neighbourhoods, citizens and the 'new governance'. Subversive citizens: power, agency and resistance in public services.

Tan, S. F. \& Artist, S. (2013). Strategic Planning in Australian Local Government: A comparative analysis of state frameworks, Australian Centre of Excellence for Local Government, University of Technology, Sydney.

Victorian Auditor-General's Office (VAGO). (2015). Public Participation and Community Engagement: Local Government Sector: Better Practice Guide, 
https://www.audit.vic.gov.au/sites/default/files/20170510-PP-Local-Gov.pdf accessed 15 May 2019.

Victorian Auditor-General's Office (VAGO). (2017). Public Participation and Community

Engagement: Local Government Sector,

https://www.parliament.vic.gov.au/file_uploads/VAGO_PP-Local-

Gov qQN5QyHk.pdf accessed 15 May 2019

Victorian Local Government Act 1989,

http://www.legislation.vic.gov.au/domino/web_notes/ldms/ltobject_store/ltobjst6.nsf/dd e300b846eed9c7ca257616000a3571/32807739dafb424aca2578db001b8014/\$file/89-

11aa109a\%20authorised.pdf accessed 24 November 2019

WALGA [Western Australian Local Government Association]. (2008). The journey:

Sustainability into the future. Shaping the future of local government in Western

Australia'.<

https://walga.asn.au/WalgaWebsite/media/WALGA_Media/LocalEyeImages/Final-

SSS-Report-Dec-2008.pdf >. Consulted 26 November 2019.

$\underline{\text { Online Archive of Submissions }}$

Webarchive - yourcouncilyourcommunity.vic.gov.au

http://web.archive.org/web/20190307201735/https://www.yourcouncilyourcommunity.vic.go v.au/previous-consultation

Discussion Paper submissions -

http://web.archive.org/web/20190307230755/https://www.yourcouncilyourcommunity.vic.go v.au/submission? preview=true accessed 6 November 2019

Directions Paper submissions -

http:/Nweb.archive.org/web/20190307230920/https://www.yourcouncilyourcommunity.vic.go v.au/Directionpapersubmissions - accessed 6 November 2019

Exposure Draft submissions -

http://web.archive.org/web/20190307201627/https://www.yourcouncilyourcommunity.vic.go v.au/ExposureDraftLocalGovernmentBillSubmissions accessed 6 November 2019 